\title{
Latter-day Mother Irelands: The Role of Women in Michael Collins and The Wind that Shakes the Barley
}

\author{
By Pilar Villar-Argáiz \\ University of Granada, Spain
}

Copyright (c) 2007 by Pilar Villar-Argáiz. This text may be archived and redistributed both in electronic form and in hard copy, provided that the author and journal are properly cited and no fee is charged for access.

\begin{abstract}
Despite the experimental and subversive work of Irish feminist filmmakers such as Pat Murphy and Margo Harkin in the 1980s, as Gerardine Meaney has contended, "the image of woman as Ireland, Ireland as woman, remains powerful and pervasive in the new Irish cinema” (1998: 250). The cinematic convention of representing Ireland through female characters becomes particularly relevant in two recent Irish historical films: Michael Collins (1996), directed and written by Irish Neil Jordan, and The Wind that Shakes the Barley (2006), written by Scottish Paul Laverty and directed by English Ken Loach. In their dealing with themes such as military occupation, colonisation and the heated debate about the Treaty, both films maintain the nationalist rhetoric that represents Ireland as a woman/mother in a direct manner. Over the course of this essay, I shall try to chart the implications of both films' representations of women, with a view to demonstrating how, even at present, the trope of Mother Ireland continues to be deep in the national unconscious.
\end{abstract}

Key Words. Cinematic representations of Ireland; Michael Collins; The Wind that Shakes the Barley; trope of Mother Ireland; female republican activism.

Resumen. A pesar del trabajo experimental y subversivo llevado a cabo en los años 80 por cineastas feministas de la talla de Pat Murphy y Margo Harkin, la asociación simbólica de Irlanda con el mito de la Madre Tierra (Mother Ireland) sigue estando vigente en el cine irlandés del siglo XX, tal y como subraya Gerardine Meaney (1998: 250). Dicha representación del papel de la mujer como madre y símbolo del país adquiere especial relevancia en dos películas recientes sobre la historia de Irlanda: Michael Collins (1996), dirigida y escrita por el irlandés Neil Jordan, y El Viento que Mece la Cebada (2006), escrita por el escocés Paul Laverty y dirigida por el inglés Ken Loach. Al abordar temas tales como la ocupación militar, la colonización inglesa, y el acalorado debate sobre el Tratado Angloirlandés, ambas películas mantienen de forma directa la simbiosis entre madre, mujer y nación. Tras analizar el papel que ejercen los personajes femeninos en ambas películas, este artículo pretende demostrar la gran influencia que el mito de Mother Ireland continua ejerciendo en el subconsciente nacional.

Palabras clave. representaciones cinematográficas de Irlanda; Michael Collins; El Viento que Mece la Cebada; representación simbólica de la mujer en la cultura irlandesa; el mito de Mother Ireland; mujeres militantes en la Guerra de la Independencia y la Guerra Civil irlandesa.

\section{Introduction}

In "Landscapes of Desire: Women and Ireland on Film”, Meaney (1998: 238) explains how films set in Ireland tend to describe landscape as a "simultaneously gendered (as feminine) and politicized" category, retaining the "metaphoric relation of woman and land". According to this critic, there have been two 
prevailing images of women in cinematic representations of Ireland throughout the twentieth century (238-245). On the one hand, we come across "the wild Irish girl", a rebellious, independent, seductive, and sweet heroine of "red or very dark hair" and "moral ambiguity" (240). This female image constitutes the main character of films such as Hungry Hill (Brian Desmond Hurst) and Captain Boycott (Frank Launder), both produced in Britain in 1947, and others such as The Quite Man (John Ford 1952) and This Other Eden (Muriel Box 1959), produced in the States and Ireland respectively. On the other hand, we encounter the prevalent image of the "suffering and nurturing mother", a trope that is more recurrent in Irish literature than in film, "possibly because the romantic conventions of mainstream Hollywood do not accommodate it as easily” (243). In cinema, this figure can be noticeably traced back to films such as Rory O'More (Sydney Olcott 1911) and The Informer (John Ford 1935). According to Meaney, both feminine representations maintain the conventional allegory of 'Ireland as woman', a tradition that goes back to the myth of the sovereignty goddess, and that was later revived by both colonial and nationalist discourses, most famously in Yeats's play Cathleen ni Houlihan (1902).

Meaney's (1998: 250) main argument is that, despite the experimental and subversive work carried out in the 1980s by Irish feminist filmmakers such as Pat Murphy and Margo Harkin, "the image of woman as Ireland, Ireland as woman, remains powerful and pervasive in the new Irish cinema". One common concern of contemporary cinema in Ireland is to explore previously taboo subjects such as unmarried pregnancy. As Pramaggiore (2006: 110-111) explains, films like The Playboys (Gillies MacKinnon 1992) and A Man of No Importance (Suri Krishnamma 1994), among others, subversively revolved around the plight of Catholic women who become pregnant outside of wedlock, in order to respond publicly to the controversial debate that Ireland was experiencing in the 1980s and 1990s around issues such as abortion and contraception. While Gibbons (1992: 13) sees these films as powerfully subversive in their challenge to "the official discourses of father and fatherland", Meaney (1998: 25) views them as merely another instance of the persistence of the trope of Mother Ireland: "The now sexual, often pregnant, female body still suffers and still embodies the nation's suffering”. Ging (2000: 12) agrees with Meaney in her analysis of how stereotypical maternal images have been revived in contemporary productions such as Into the West (Michael Cormac Newell 1992) and Angela's Ashes (Alan Parker 1999).

This cinematic convention of representing Ireland through female characters becomes particularly relevant in two recent Irish historical films: Michael Collins (1996), directed and written by Irish Neil Jordan, and The Wind that Shakes the Barley (2006), written by Scottish Paul Laverty and directed by English Ken Loach. ${ }^{1}$ Both films deal with the birth of the Irish modern nation and chart the divisions that follow the signing of the Treaty in 1921 by focusing on the (homosocial or brotherly) affection between Irishmen who end up on different sides in the Civil War. ${ }^{2}$

\footnotetext{
${ }^{1}$ As Butler Cullingford (200: 214) has noted, "the term 'Irish film' is a contested one" due to the fact that some cinematic representations of Ireland are "financed by American corporations and governed by Hollywood narrative conventions". This is the case of the two films under discussion: the first, a Warner Bros production, and the second an IrishBritish-Italian-German-Spanish co-production. In any case, and due to the fact that both films have been considered by the press as Irish, I will use this term throughout the course of the essay.
}

2 Because they deal with a crucial period in Irish history, both films have aroused a certain amount of political controversy. First of all, they have received accusations, mostly from conservative British newspapers, of being anti-British and propagandistic in their portrayal of the British as Machiavellian evil oppressors and the IRA as goodintentioned freedom fighters. Secondly, and as Arts Minister John O’Donoghue claimed, both films are also controversial because they explicitly take opposite sides in the debates that followed the Treaty in 1921 (McConnell 2006: 4). Whereas "Michael Collins was seen as a Fine Gael film" in its negative portrayal of de Valera, The Wind that Shakes the Barley "come[s] down unquestionably on the anti-Treaty side" by sympathizing with the republican cause. Finally, both films have drawn inevitable parallels between the Ireland of the 1920s and the current political situation. Whereas 
Whereas Michael Collins offers an epic biography of a crucial figure in Ireland's War of Independence, Loach's production tries to move away from "the conventional practices of the [Hollywood] industry" (McGurck 2006: 20) by focusing on fictional and anonymous freedom fighters. Michael Collins excludes any consideration of the IRA's flying columns by concentrating exclusively on the urban guerrilla war led by Collins in Dublin. In contrast, The Wind that Shakes the Barley deals directly with how those turbulent years in Ireland's history were experienced in the countryside, particularly in West Cork.

In their dealing with themes such as military occupation, colonisation and the heated debate about the Treaty, both films maintain the nationalist rhetoric that represents Ireland as a woman/mother in a direct manner. Over the course of this essay, I shall try to chart the implications of both films' representations of women, with a view to demonstrating how, even at present, the trope of Mother Ireland continues to be deep in the national unconscious.

\section{2. 'She's a voice like an angel': Jordan's exploration/restoration of sexual boundaries}

In its reconstruction of one of the most crucialperiods in Ireland's history, Michael Collins combines in an admirable way the excitement of the thriller and the passion of intense romance. Like Ken Loach's historical adaptation, Jordan approaches the complex network of political events from the point of view of the protagonists themselves, under the belief that history only takes shape through the rather privatized perception of ordinary men and women: "people don't live history, they live their lives" (interview with McSwiney 1996: 12). This intermingling of the political and personal spheres in the film not only increases its dramatic effect, but also functions,

\footnotetext{
(...2) Michael Collins has brought about resonances about the Troubles in Northern Ireland, much to Jordan's regret, Loach has deliberately encouraged associations between the British occupation of Ireland and the present occupation of Iraq (Coleman 2006: 1). For those opposing Jordan's film, see Roberts (2000) and Harris (1996). For accusations of Loach's directional approach, see James (2006), Harris (2006a, 2006b), McKiernan (2006) and Landesman (2006).
}

according to Gibbons (1997: 50), as “a marketing device, a narrative hook to render the story intelligible to non-Irish audiences unfamiliar with the historical background".

Precisely because of this, Jordan intermingles the public story of the country with Collins's and Boland's rivalry for Kitty's affections, who they met while electioneering in County Longford. Kitty Kiernan, played (perhaps unconvincingly) by Julia Roberts, ${ }^{3}$ belongs to a very prosperous merchant family in the market town of Granard, County Longford (Ó Broin 1996: 3). When Collins and Boland stay in the Greville Arms Hotel, owned by Kitty's family, they both feel attracted towards this charming, stylish, and goodlooking girl. In the film, Jordan suggests that the rivalry between the two suitors partly provoked the Civil War. ${ }^{4}$ When Harry Boland returns from America, he acknowledges that Kitty is more attracted to Collins than she is to him. The subsequent split in their close friendship mirrors the oncoming Civil War,

3 Critics such as Carey (1999: 24) argue that Roberts fails to imitate the Irish accent and others plainly state that her performance "is pretty woeful" or, at best, "absurd” (Browne 1996; Clayton-Lea 2001: 71). In fact, Jordan (1996: 30-31) has admitted being initially worried "by the complications a big star would bring" to the role of Kitty Kiernan, but he finally decided to cast Roberts, because, "[o]f all the actresses I have met for the role, she is the one who knows most about it”.

${ }^{4}$ As Meaney (1998: 246) argues, “[a]rgument over land is a frequent plot device and it is almost always linked to a dispute over or with a woman”. This also seems to be the case of Collins's and Boland's fight over Kitty's love. Jordan's visualization of the political relationship between these two friends through the more intimate romantic relationship both of them have with Kitty can be traced back to the tradition of the 'Colleen Bawn' films produced at the beginning of the $20^{\text {th }}$ century. Meaney (1996: 238-239) explains how these cinematic reinterpretations of Gerald Griffin's 1829 novel The Collegians approached the political sphere "through romance narratives”. Nevertheless, whereas in films such as The Colleen Bawn (W.P. Kellino 1924) and Willie Reilly and His Colleen Bawn (John MacDonagh 1920) marriage symbolizes ethnic, religious or class reconciliation, in Michael Collins it is precisely romance that provokes political division. 
which will cause a rift in the relationship between Collins and Boland. ${ }^{5}$

In spite of Jordan's suggestion that Kitty's decision to marry Collins in some way determined the course of historical events, in fact, she does not seem to adopt any sort of relevant role in the film. Kitty's appearance only serves as a channel to portray the complex set of political relationships that Jordan depicts. In reality, Collins and Boland yearn for each other. Unlike the delicate and platonic romance both of them have with Kitty, theirs is a passionate and homosocial relationship, filled with intense love, desire and jealousy. ${ }^{6}$ The love triangle established between Collins, Boland and Kiernan parallels the political triangle that is comprised of Collins, de Valera and Boland, as observed in the famous scene of the Lincoln Jail escape. ${ }^{7}$ Like Kitty, de Valera

\footnotetext{
${ }^{5}$ Although it is historically documented that these two friends courted the same woman, Harry's rejection of the Treaty and "his distancing himself from Collins” was, as Coogan (1991: 281) explains, "politically, not romantically motivated".

${ }^{6}$ When in one of the initial scenes they observe a bride at a railway station, Collins tells Boland "Maybe we should settle down", to which Boland replies "Just the two of us" (Jordan 1996: 97). The bonds between these two friends are not only emotional, but also intensively physical: they embrace, grip each other's heads and arms, fix their ties, wrestle "like two schoolboys" (Jordan 1996: $97,125)$, and even share the bed several times. Mick is the masculine figure of the couple: he appears as a "tough and burly" character, while Boland is feminized as "slim and fine-bones" (Jordan 1996: 96). Kitty's role is reduced to facilitating the homosocial desire between both friends. When she and Collins go to the station to bid a sad farewell to Harry, she tells Collins "He's leaving me, Mick”, and he replies, "Thought he was leaving me” (Jordan 1996: 144). This triangular relationship is further emphasized when Kitty tells Boland after a sumptuous dinner: "You without him. Him without you. I can't imagine it” (Jordan 1996: 173-174).

${ }^{7}$ Influenced by the reading of a local newspaper article at the time, Jordan (1996: 35) decides to dress de Valera in a tart's fur coat and a feathered hat. Escorted by Collins and Boland on either side, de Valera has to pretend he is a tart as they walk along the jail walls lined up with prostitutes. For a critical assessment of this scene, see Hooper (1997: 26), Butler Cullingford (2001: 217), and Rockett and Rockett (2003: 169).
}

will find himself displaced by Collins's intense relationship with Boland, which will motivate his later attempt to keep them apart by insisting that Harry should accompany him to America.

Although much has been written on Jordan's complex structure of relationships and the homoeroticism (or sexual ambiguities) displayed by these three male characters, the role played by Kitty Kiernan and other women in the film has not been sufficiently explored. In what follows, I will try to reduce this critical imbalance by focusing on how this filmmaker portrays female characters as social and political subjects with a significance of their own. As the authors of Neil Jordan: Exploring Boundaries claim, one of Jordan's main interests in his prolific career as a filmmaker is to challenge and blur all sorts of fixed categories: "Jordan is always drawn to the 'in between' - the confusion, richness and complexity at the site of boundaries, whether these borders are social, political, psychic, sexual or cultural; or are they physical or abstract” (Rockett and Rockett 2003: 2). This subversive approach is observed in previous films such as The Crying Game (1992), where Stephen Rea features as a confused member of the IRA who falls in love with a black English transvestite (Dwyer 1996). In Michael Collins, Jordan also transgresses sexual boundaries in his depiction of Collins, Boland and de Valera, as I have already noted. However, when it comes to representing his female characters, Jordan is far less subversive. In fact, he surprisingly reinforces patriarchal notions of femininity and motherhood.

In contrast to the complex figure of Michael Collins (on the one hand, he represents hegemonic masculinity, on the other, he is latently homosexual), Kitty is described as a much simpler character. As Hopper (1997: 16) explains, Jordan is being loyal to the "stock conventions of character": "virtuous hero", "vicious villain" and "virginal heroine". Indeed, the 'big fellow' is glamorized as a handsome, brave, passionate and charismatic leader, always ready to buy his round and to make a humorous comment despite the hardness and danger of the situation he is enduring $^{8}$. His relationship with Kitty is also

\footnotetext{
${ }^{8}$ In contrast to the British, who are portrayed as brutal oppressors, Collins is presented as a benevolent fighter who only takes up arms because
} 
romanticized, when in reality it has been documented that he had other relationships with women (some even talk about "his legendary lasciviousness" [Hopper 1997: 25]). The film in fact does not mention Collins's relationship with Hazel Lavery, "one of London's most brilliant and beautiful society hostesses" (Gritten 1995: 6) ${ }^{9}$. During his stay in London, Collins was treated as a celebrity by fashionable society and was hosted by Lady Lavery, the wife of the painter Sir John Lavery (Ryan 1996: 113-114). It was widely thought at the time that Collins and Hazel had a love affair. Nevertheless, opinions among historians are divided as regards the truthfulness of such an affair. Whereas Ryan (1996: 162-3) argues against the veracity of this relationship, others such as Dillon-Malone (1996: 28-30) believe that Collins had "a fiery affair with Lady Lavery”, while Kitty Kiernan, "in contrast, had more of a girl-next-door appeal for him". In spite of this, there is empirical proof that Collins had other kinds of dalliances in his life (Ryan 1996: 57).

At the other extreme of Collins's conventional heroic mould, we encounter sweet Kitty Kiernan, a charming local girl of refined manners. Mick and Kitty do not really seem to have much in common. In the face of such a powerful and important political figure, a person whose impassioned speeches are able to fire up a crowd, Kitty's character is, by contrast, deeply apolitical, "curiously chaste" (Hopper 1997: 25), fragile, and even immature at times. As can be seen, both male and female

\footnotetext{
(..8) “they’ve left us no way out” (Jordan 1996: 135). He even addresses the enemy with respect, as when he tells the Royal Irish Constabulary officers after his squad raids the police barracks: "Gentleman. We're relieving you from your responsibilities" (Jordan 1996: 106). Furthermore, he never kills anyone in the film, (although, as Ryan [1996: 53] explains, there is no evidence that he ever did so), and repeatedly tells his squad of young soldiers that he would understand it if anyone wanted to back out from the fight (Jordan 1996: 126, 151).

${ }^{9}$ Jordan (1996: 13) justifies this omission by arguing that it would increase the film's budget (as it would have implied including new characters and the new setting of London). In the diary that prefaces his screenplay, Jordan admits having taken "greatest" liberties with historical facts for the sake of narrative dynamism (14).
}

protagonists seem to fit almost perfectly the conventional standards of brave hero and submissive or vulnerable maiden. When commenting on the "lack of depth of Kitty's character”, Rockett and Rockett (2003: 172173) note that her apolitical personality "renders her somewhat irrelevant to the film, which though 'about' the life of Collins is foremost a political exploration". These critics go on to comment that, precisely because of this, the film cannot "be made to serve some political feminist agenda, in which Kitty could be read as such a revolutionary" (173). In any case, we should bear in mind that Jordan is being faithful to Kiernan's personality in real life. In one of his interviews, this filmmaker claims: "[s]he was not Rosa Luxemburg, she wasn't involved in politics, so, in many ways, people might find the part slightly underwritten but that's what the character was" (in McSwiney 1996: 13). Indeed, Jordan is right. As Coogan (1991: 282) explains in his bestselling biography of Collins, Kitty had no interest whatsoever in Collins's political activities. This is reflected in one of the letters she sent to Collins while he was negotiating the Treaty in London: "With me nothing seems to matter except that love between the two of us” (in Ryan 1996: 120). What Kitty was really interested in was winning Mick's affection and securing her future by getting married. As Ruane reminds us: "Women made careers out of marrying men at that time, and Kitty realised that Mick Collins promised her the career of her life. At last, she was set to become herself" (1996). Furthermore, she "preferred to party than to parade", unlike Mick's previous girlfriend Dilly Dicker, who deeply engaged in Collins's political activities, helping him with intelligence (Ryan 1996: 58). As Ryan claims: "It is interesting to note that Kitty Kiernan is the one woman in his life who did not play any significant part in his work" (14).

Kitty's apolitical stance and her allegedly trivial concerns are emphasized in Jordan's dramatic reconstruction of the life of Collins. When they first meet at Granard, Kitty sings a song about love and the prospect of a "wedding day", which contrasts markedly with Collins's song about British imperialist rule (Jordan 1996: 102-103). Relying on the filmic conventions of the gangster genre, Jordan intercuts the Bloody Sunday sequence with a 
romantic scene of Collins and Kiernan at a suite in the Gresham Hotel. ${ }^{10}$ Instead of talking about what was happening that night in a straight forward sense (the assassinations of the British secret agents by Collins's 'Twelve Apostles'), Kitty attempts to draw the conversation to what she is really interested in, and this is Collins's personal feelings for her:

\begin{abstract}
KITTY: You've sent your boys out, haven't you?

...

KITTY: It's written on your face. Every step they take. Like so many valentines. Delivering bouquets.

...

KITTY: Do they deliver a love note, Mick? With the flowers?

[COLLINS says nothing]

KITTY: What does it say?

$\cdots$

COLLINS: It says leave us be -

KITTY: Is that all? Not very romantic... (Jordan 1996: 159-161).
\end{abstract}

Kitty's disappointment with Collins's answer ("Is that all? Not very romantic...") ironically contrasts with the seriousness of the situation. A scene that takes place several minutes before the above quoted exchange equally demonstrates Kitty's trivial nature. When Collins arrives at Vaughan's hotel, and forcibly removes Kitty to a safer location, she protests: "have you never heard of common courtesy?” (Jordan 1996: 152). Kitty's childish disposition and her inappropriate concern with manners are further emphasized as they arrive at the Gresham hotel and she stubbornly complains twice "You're hurting me ... I said that you're hurting me!” (154). Kitty stands, in this sense, as a capricious character solely focused on herself and virtually oblivious to the pressures and dangers under which Collins is labouring. These scenes, intercut with the brutal assassinations, give us a clear insight into her attitude to life and her complete disinterest in the serious political events of the time.

\footnotetext{
$\overline{10}$ Some critics have perceived some analogies between Michael Collins and The Godfather II (Francis Ford Coppola 1974), a film that also intercuts romantic scenes and slaughter sequences (Browne 1996; Crowdus 1996: 18; Gibbons 1997: 50).
}

In any case, it is not only political disinterest that Jordan emphasizes when describing Kitty's character. Collins's fiancée is depicted as a totally vulnerable and defenceless woman who needs the security of male protection. Just before leaving for America, Boland asks Collins to take care of Kitty, as "She'll need looking after while I'm gone..." (Jordan 1996: 144). Collins takes his friend's advice seriously. It is Collins who prevents Kitty's search by a group of British solders at the railway station and later saves her from being killed by a gunman who fires at them through an office window $(145,191)$. Twice in the film, Collins reminds Kitty of the promise he made to Boland "to look after" her $(145,152)$. In this sense, Kitty is transformed into an object of protection, rather than a subject who can act on her own. ${ }^{11}$ Furthermore, and in spite of her voluntary refusal to enter the (masculine) realm of politics, Kitty is deprived of information about what is occurring beyond her private sphere. On the eve of Bloody Sunday, Kitty asks Collins why he insists that she leave Vaughan's Hotel with him, to which he replies: "Don't ask questions" (Jordan 1996: 153). Her exclusion from the masculinized world of politics is further emphasized in the Gresham Hotel, when Collins refuses to tell Kitty what is happening that night: "What's happening tonight, Mick?”, "You don't want to know", he answers (157). A reading between the lines discloses hidden patriarchal assumptions that deny women's access to knowledge, and therefore their participation in the wider political sphere. Kitty's passivity and lack of agency is reinforced, not only by her personal disinterest in external matters, but also by the edicts of patriarchy.

Kitty's subordinate and apolitical status runs counter to her abrupt transformation in the film into a pseudo political activist. In scene 179, after the Treaty has been signed, Collins (the leader-turned-statesman) is addressing a

\footnotetext{
${ }^{11}$ Being a feminized character, Boland appears, just like Kitty, as a vulnerable person who needs the protection of men. In the midst of the Civil War, Collins risks his life to safe Boland, who is trying to escape from the bullets of a Free State squad chasing him. When he is killed by one of his soldiers, Collins forcefully drags this young soldier by the coat, and tells him "you were meant to protect him” (Jordan 1996: 201).
} 
large assembly gathered in Granard square. Kitty is watching the scene from one of the upstairs windows of the Greville Arms's hotel. This threshold location advances her attempt, for the very first time in the film, to step out of the (domestic) private sphere and enter the public domain. As some Republicans try to boycott Collins's speech, Kitty pushes through the mayhem, predominantly male, and puts a gun to the head of an anti-Treatyite, shouting "Now let the man speak!" (Jordan 1996: 188). Miraculously, Kitty is transformed from a frivolous local girl, only interested in getting herself a man, "into a winking Annie Oakley with a Big T in her hands" (Myers 1996). Therefore, it is not surprising that critics such as Crowdus (1996: 15), amazed by these contradictions in her personality, claim that Kitty's "brief scene of gunplay ... is completely out of character", taking into account that her appearance in the movie only seems to fulfil the role of adorning Jordan's production with "romantic interest". Indeed, and in spite of Jordan's well-intentioned attempt to implicate Kitty in Collins's political agenda, it may be ironical that she finds time to put her black hat on, as she rushes to the town square to paralyse the Republican boycott. Minutes later, and while she minds the wound on Collins's head (he has been hit by a rock), Collins tells her: "God, you put your heart across me, Kitty", and she answers: "I like the sound of your voice, Mick" (Jordan 1996: 188). Although Kitty becomes a solid Treaty supporter not for the sake of her political beliefs but because of her relationship with Michael, she seems at last to comprehend the terrific strain under which he labours. The stark contrast between her concerns and his disappears in this scene, as both lovers, for the very first time, explicitly talk about politics and de Valera's inflexible attitude towards the Treaty.

Despite the bravery exhibited by Kitty in this swift heroic act, her character seems to return to the safely ascribed role of passive and submissive lover. Towards the end of Jordan's film, there is a series of scenes in Clery's shop, where Kitty is buying a wedding dress, and these are intercut with Michael's wry conversation with O'Reilly about his marriage, moments before his assassination in Béal na mBláth: "Shall I invite the whole country. Call it marital diplomacy. Dev as the best man.
Lloyd George and Winston Churchill as the bridesmaids" (Jordan 1996: 211). Jordan here uses the resources of colonial discourse, particularly its tendency to represent England and Ireland in sexualized terms (as a hierarchical marriage between John Bull and Hibernia). It is interesting to note how Collins's discourse deconstructs the conventional allegory of Ireland as a woman: whereas de Valera (as a representative of Ireland) is masculinized as "best man", Lloyd George and Winston Churchill are feminized as English bridesmaids. In any case, this subversion of gendered national roles does not apply to Kitty's appearance in the scene. Just at the very moment an Irregular shoots Collins in an ambush, an attendant drapes a bridal veil and wreath over her head. She looks at herself in the mirror, clearly fascinated by the sight, while holding a white wedding dress over her body. As Hopper (1997: 28) explains, Kitty is presented "in the posture of the Madonna". Christian martyrdom (or the death of a great man who might have redeemed his people) is therefore associated with the female allegory of Ireland as a young maiden with virginal aspect and pale skin ${ }^{12}$. Like a latter-day Virgin Mary, Kitty embodies passivity, frigidity, sanctity and submissive suffering. This mother-spouse stereotype is further emphasized in the penultimate scene, where Kitty, "in an anguish of grief”, learns about Collins's death (Jordan 1996: 215). As Meaney (1998: 245) explains, it is not coincidental that Kiernan is wearing "a green coat" when "lamenting her fallen hero", for this enhances her association with grieving Mother Ireland. Indeed, the symbolic significance of Kitty's garments throughout the film is noteworthy. Up to scene 179, Kitty is almost always dressed with a white blouse, a colour that symbolizes virginity and feminine purity. Afterwards, she wears a black dress, indicating her near widow status, as two of her suitors

12 The implications of this Catholic iconography become even more obvious if we bear in mind the resonances of Collins as Christ throughout the movie: he is almost the same age as Jesus when he was crucified and he is allegedly betrayed by one of his "Twelve Apostles". On the night before his assassination, we see de Valera, shivering uncontrollably beside a hayrick. Moved to tears by Collins's words, he claims: “Oh Jesus, Mick, God forgive me, Harry” (Jordan 1996: 209). 
face death. It is not until the film is nearing its conclusion that Kitty wears a green coat, which parallels the beautiful green fields that, moments before, Collins and O'Reilly were passing through in convoy. ${ }^{13}$ Kitty is therefore transformed from a passive and submissive 'angel in the house' into a sorrowful Mother Ireland, mourning the death of one of her sons. In this sense, she becomes at the end both an obedient wife and an asexual mother, in other words, a symbol connected with spirituality rather physicality.

It is worth noting that women in this film appear almost as spectral presences and this makes a comparison between them and the mythical and mystical Mother-Ireland figure of Cathleen ni Houlihan seem very tenable. In scene 17, Collins and Boland witness a wedding party at a railway station. The bride is wearing a white silk dress and a veil trimmed with white flowers, (a garment almost identical to the one Kitty wears towards the end of the film). Her figure gradually "emerge[s] from the steam like a wraith" (Jordan 1996: 97). Her appearance behind clouds of steam enhances her unearthly and mystical status. She represents an untouchable ideal of eternity and beauty, an illusion that only exists in the mind of male heroes. Jordan introduces this figure for the sole reason of strengthening the homosocial relationship between Collins and Boland, who start talking about settling down, "just the two" of them (97). In the Bloody Sunday sequence, Kitty's figure is also surrounded by an air of mysticism. A close-up of the couple shows Kitty's face in a grey gloomy light, while Collins embraces her from behind and kisses the back of her hair. Minutes later, Kitty is lying on the bed, facing the ceiling with her arms over her body. Jordan's (1996: 42) initial intention, as reflected in his diary, was to portray Kitty in the "shape of wife or whore beside officer". In any case, Kitty looks like anything but a prostitute. The gloomy light of the hotel room and her

\footnotetext{
13 Significantly enough, the only previous scene when Kitty wears a green coat is at Collins's office, when, after an Irregular almost kills her, she tells Michael: “They won't shoot me, Mick" (Jordan 1996: 191). This sentence could be interpreted as uttered by a Mother Ireland who thinks that her own faithful sons cannot betray her.
}

passive posture enhance her iconic status as a defeated (and almost dead) Mother Ireland, waiting for the courageous protection of Irishmen to restore her dignity and purity. When Collins sits next to her, he holds a red flower in his hand just between their faces. According to Butler Cullingford (2001: 91), this scene at the Gresham Hotel enhances "the perennial association of love with death"14. Love for the mother country is inevitably linked to the sacrifice and death of this tragic hero. Kitty embodies this heroic ideal, this utopian Ireland that Collins feels compelled to fight and die for.

In this sense, rather than being a real subject with an identity of her own, Kitty personifies a spiritual dream of purity and selflessness. In one of the initial scenes, Collins and Boland are enjoying a 'musical' evening at the Greville Arms's hotel. When Kitty finishes singing "She Moved Through the Fair", Collins admiringly claims "She's voice like an angel” (Jordan 1996: 103). From her initial appearance on the screen, Kitty is deprived of individuality, something that is made abundantly clear when Collins, in the previous scene, first meets her at the backyard of the hotel:

COLLINS: You a nurse, Kitty?

KITTY: I'm nothing. I'm my father's daughter

COLLINS: And who's your father?

KITTY: He’s dead. (Jordan 1996: 102)

Kitty's role, and therefore her identity, is solely defined in terms of her father, who is, funnily enough, absent rather than present. Later in the film, the figure of the omnipresent father is replaced by that of the protective 'husband' and Kitty subsequently becomes, as Michael defines her, "Harry's girl” (Jordan 1996: 155). Thus, rather than standing

\footnotetext{
14 In fact the colour red appears consistently throughout the whole scenes of the Bloody Sunday sequence. Kitty's room and the reception at the Vaughan's hotel are decorated with red wall paper and red lamps and the sign 'Hotel' on the front door is red as well. When the squad of 'Twelve Apostles' meets in the dark backstage of a theatre in order to arrange the assassinations, the only thing that stands out in the dark background is a bunch of red flowers on a table. Similarly, the rooms where some of the killings occur are strikingly red.
} 
independently, Kitty acquires her identity only in her role of submissive daughter or girlfriend. Furthermore, she seems to be perfectly willing to submit to the passive roles that she has been assigned.

The argument might be made then that Jordan maintains the patriarchal convention of the woman as a beautiful angelic Madonna, wholly passive, contemplative, submissive, graceful and selfless. Apart from Kitty, the film only provides room for two other women. The first of these is Rosie (played by Laura Brennan). Like Kitty, Rosie is described as a faithful 'angel in the house', totally fragile and submissive. As a young chambermaid working for Soames, a British commander, she assists Collins in the gathering of intelligence. From her master's wastepaper basket, she takes a list of British spies and intelligence officers, which will be very useful to Collins when he is organizing the Bloody Sunday assassinations. In any case, Jordan does not enhance the risk Rosie takes when supporting Collins's guerrilla campaign. In the following scene, it is Charlie Dalton, a young volunteer and presumably her boyfriend, who deserves the honour, for he is the one who encourages Rosie to tell Mick everything that she knows:

DALTON: Tell him about Mr. Soames, Rosie.

[Rosie is shy]

ROSIE: Well, he tips me everyday. Not like some.

COLLINS: What time does he get up?

ROSIE: I come in at nine. He's washing, you see, behind the screen, so I don't see him. I empty the basket, take the linen. And then his hand comes over the screen with a half-crown in it.

DALTON: You shouldn't take it, Rosie.

ROSIE: But he's a gentleman, Charlie.

[Collins smiles]

COLLINS: And you're a lady, Rosie. Shut up, you.

ROSIE: Thank you, Mr. Collins.

DALTON: Show him what you got from the basket, Rosie.

[Rosie smiles and takes a bundle from under her apron, hands it to COLLINS] (Jordan 1996: 150).

In the above scene, Rosie simply responds to Charlie's commands. She lacks agency, and although she presumably helps Collins with some information, she differs a great deal from those determined couriers that The Wind that Shakes the Barley portrays, as I shall demonstrate shortly. Rosie's action seems to be motivated more by her boyfriend than by her own national allegiances. She perceives Soames not as an oppressor, but as a nice "gentleman" who recognizes her work and tips her for that (much to Charlie's discontent). In contrast to Loach's filmic adaptation, Jordan presents ladylike women of gentility and fine manners who conform to the assigned position of mothers, daughters and housewives. Rather than assertive, Rosie is portrayed as a shy maiden, who gently "curtsies" when meeting Collins for the first time (Jordan 1996: 150). It is Charlie who leads the action throughout the whole scene, guiding Rosie's behaviour and words. When she finishes telling Collins about Soames, the young volunteer drags her away from the meeting, gripping her arm, as at various times throughout the movie Boland and Collins do with Kitty. Rosie's vulnerable stance is reinforced in her second (and final) appearance in the film. When one of the "Twelve Apostles" riddles Soames with bullets in his hotel bedroom, we see Charlie Dalton at the back "holding Rosie mute with a hand around her mouth" (Jordan 1996: 160). As the killing is completed, Charlie pulls his hand free and Rosie "emits one long hysterical scream" (160). Therefore, Rosie is not allowed to take part in any meaningful way in the nationalist struggle. Just like Kitty, she merely stands as a tool for men to define their masculinity and sustain and legitimate their authority.

This also seems to be the case with the second female character who appears in the film, and who Jordan (1996: 90) identifies in the cast as "Girl in Bed". In scene 161 of the Bloody Sunday sequence, one of the British spies is caught with his lover in a hotel bedroom decorated with a red sofa and red curtains, a colour indicative not only of death but also of lust and passion. Using the pretext that his wife should not witness his own murder, this British serviceman uses the cover of her body to reach for a gun, although he is eventually discovered and shot down. Suddenly, the woman screams hysterically with a Dublin accent, "I'M NOT HIS BLEEDIN' WIFE!” (Jordan 1996: 161). As can be seen, women's roles in the film are 
limited to the patriarchal duality faithful servant/lascivious whore. Furthermore, and what is even more striking, both characters (Rosie and "Girl in Bed") appear as British allies, socialising, befriending, and consorting with 'the enemy': Rosie is ultimately loyal to her master Soames (although she betrays him, she seems to be totally oblivious of the dreadful consequences of her actions), and the other woman sleeps with a British officer, an action which the IRA punished sometimes with the penalty of death, as McCoole (2003: 74) explains.

All this may lead to the conclusion that Jordan is more interested in portraying the valiant actions of male heroes than in stressing women's active participation in the War of Independence and the Civil War. Although the assessment of Jordan's fidelity to historical facts is beyond the scope of this paper, a brief contrastive analysis of female republican activism and Jordan's dramatic adaptation is useful for gaining a valuable insight into his under-representation of women. The film begins with the Easter Rising of 1916, when about 1,000 Volunteers occupied the Post Office and other key buildings in the centre of Dublin. The role that Irish women played in this insurrection against the British government has been comprehensively explored by McCoole (2003: 34-58). This historian explains how as many as 200 women (most of them members of Cumann na mBan and the Irish Citizen Army) assisted the men by cooking and providing food, guarding the gates of the occupied buildings, providing medical attention to the wounded, and delivering messages, weapons and food between the various outposts and garrisons. There were even women who were "snipers", fighting alongside the men during the Rising (42). Yet, not a single woman appears in Jordan's brief depiction of the Easter Rising. As a local bulletin of the time evinces, it was a Cumann na mBan member, Elizabeth O'Farrell, who waved the white flag of surrender. ${ }^{15}$ In her personal account of the events of the Easter Rising, O’Farrell (1917: 267) explains how she

\footnotetext{
${ }^{15}$ I am deeply grateful to Graham Price for informing me about Elizabeth O'Farrell's vital participation in the Easter Rising, and also to Dr Katherine O’Donnell for providing me with a copy of The Catholic Bulletin and Book Review (April 1917).
}

was selected by Commandant P.H. Pearse to carry his message to the English Commander in order to negotiate the terms of peace. Jordan neglects to mention O'Farrell's courageous role as a mediator by depicting a man carrying the white flag on behalf of the Irish Republican Army. It is indeed true that, in his filmic reconstruction of the Easter Rising, a woman appears among the surrendered Republicans, lined up against the railings in front of the British soldiers. Nevertheless, the camera moves quickly past her, so that it is almost impossible to distinguish her.

Women's omission as political activists during the War of Independence becomes more obvious as the film proceeds. As McCoole (2003: 76) explains, historical evidence shows how women such as Máire Comerford provided safe houses for Michael Collins. Jordan only makes passing references to women's importance in sheltering the rebels. When in scene 34 de Valera is arrested at his house, the camera catches glimpses of a woman and her child (presumably Dev's wife and daughter). As they cannot return to their own homes, Collins decides to spend the night there, because, as he tells Boland: "It's the safest house in Dublin now" (Jordan 1996: 112). Nevertheless, any opportunity Jordan might have had to grant importance to women's role as providers of safe houses is skipped in favour of an intimate scene between Collins and Boland, sitting on the steps at the entrance of the house while one of them lights a cigarette. At another moment in the movie, Collins, Boland and de Valera stay in another house, owned by a working-class mother (Jordan 1996: 141). Just as a British squad is about to raid the house, the three men manage to escape from the backyard. Before leaving the place, Collins finds time to salute this mother, who is with her daughter washing some clothes. Nevertheless, the camera passes too quickly and it is almost impossible to see them.

In this sense, even though ordinary women are present in the film (we see at different stages a church, market, cinema and abattoir densely packed with both men and women), they only appear in the background and men tend to monopolize the action. Jordan's movie makes no mention of Collins's strong team of female intelligence workers who were regular carriers of dispatches. As McCoole (2003: 78- 
79) and Ryan (1996: 41) note, Collins relied heavily on women in order to accumulate information about the members of the British Intelligence. His "spy network" included women such as Eileen McGrane, Kathleen McKenna, Patricia Hoey and Sinéad Mason, who "worked for him as administrators and secretaries"; Máire Comerford, Sighle Humphreys and Leslie Price, who "acted as couriers", and other women such as Jennie Wyse Power, Márie Comerford, Brigid Lyons Thornton and Moya Llewelyn Davies, among others, who collaborated in the espionage (McCoole 2003: 78). Collins also depended on the support of spies such as Nancy O'Brien (his cousin) and Lily Mernin, who worked in the British administration (Ryan 1996: 45-47). All these women, in some way or other, "made possible the elimination of eleven members of British Intelligence", in what became known as Bloody Sunday (McCoole 2003: 79). In Jordan's adaptation, the only woman to adopt a pivotal role in the support of Collin's campaign is Rosie. Yet, as we have seen, she is represented as being utterly vulnerable, and motivated more by the encouragement of her partner than by her own nationalist ideals.

Therefore, Michael Collins overlooks the role women actually played in the urban guerrilla warfare. Jordan portrays female characters who are either deeply dependent on men or utterly silent. At one stage in the film, when British officers are about to raid Collins's office, we get a quick glimpse of his staff: among three men (one of them Collins), we see a woman, presumably a typist, who grabs some files and quickly leaves the room (Jordan 1996: 131). This woman might be Sinéad Mason, Collins's "secretary and confidential typist", "almost his left hand" throughout the War of Independence (Ryan 1996: 65). In spite of her pivotal significance in Collins's life, Jordan grants her no importance whatsoever and she is allowed no speaking part. This silence also extends to the female clerk who helps Collins to find his way out in the following scene. When he asks her: "Beg your pardon Ma'am, how do I get out of here?", she simply signals to the door and he answers "Grand!" (Jordan 1996: 132). In the heated debates that follow the signing of the Treaty, the discussion is held solely by men, in contrast to The Wind that Shakes the Barley, where women are active participants. Even though there are some women in the Dail chambers, Michael Collins, Arthur Griffith, Cathal Brugha and Eamon de Valera are the ones to take the floor during the three minutes that the scene lasts. When the Treaty is ratified by a majority of seven votes, most of these women leave as a protest against the ratification of the Treaty. At least, Jordan is here giving some room to female agency, as it is indeed documented that most Cumann na mBan members were anti-Treaty (Ryan 1996: 135; McCoole 2003: 86). Nevertheless, a general overview of women's appearance in the film shows that they are virtually and politically cut off.

\section{3. 'Selling out a mother': Loach's flesh-and- blood national icons}

The Wind that Shakes the Barley tells the story of the Irish War of Independence and the subsequent Civil War from the perspective of two brothers who belong to a middle-class rural family: Damien (played by Cillian Murphy) and Teddy (played by Padraic Delaney). Damien is a medical student who is initially reluctant to participate in the War of Independence. As he is about to emigrate to London to work as a doctor, he becomes politicized by two brutal incidents he witnesses in his local village: first, one of his neighbours is beaten to death by the Black and Tans simply for declining to give his name in English, and secondly, as Damien is about to get into the train, he witnesses how a group of Tans brutally assault a guard and train driver who refuse to transport British soldiers and weapons. After this, Damien joins the IRA flying column led by Finbar. Damien's older brother, Teddy, is, from the start, deeply committed to the republican cause. Although both brothers fight together through the War of Independence, after the Treaty is signed, they find themselves on opposite sides in the Civil War. Whereas Teddy supports the new Irish Free State, Damien and other volunteers defend the need to continue fighting. At the end, Damien is executed by a firing squad. His brother Teddy, now an Irish Free State officer, is the one who gives the order.

Loach's film contrasts markedly with Jordan's biopic reconstruction of this period. Although both of them deal with the same crucial historical moments in Ireland's fight for independence, there are three main differences 
in their approach to the past. First of all, Loach is, unlike Jordan, highly committed to socialism, and that is why he focuses more deeply on class distinctions. This blend of different voices is observed in the members who volunteer to join the Flying Column: they are sons of accommodated farmers, landless labourers, blacksmiths, barmen, shopkeepers and even artisans. Secondly, Loach's way of handling the heroism of Irish rebels is radically different from Jordan's epic treatment of Michael Collins. As he has admitted in an interview, he and screenwriter Paul Laverty are deeply aware of how essential it is "not to romanticize violence": "This is not a Hollywood movie, so I hope people can see the complexity and the hurt as well as a story true to the times. That's the intention" (in Dwyer 2005: 8). Clearly, The Wind that Shakes the Barley does not yield to the easy sentimentality of heroic actions. The characters' "bravery and idealism" is counteracted by their constant "contradictions, inconsistencies and human failings" (Ferriter 2006: 21). Furthermore, and in contrast to Michael Collins, Loach introduces more violent scenes, reflecting the Irish past in all its rawness and harshness (as when Teddy is subjected to gruesome torture, his fingernails being plucked out with a pair of

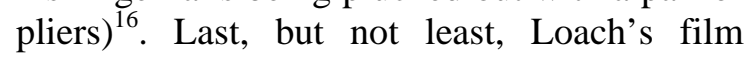
opposes Jordan's conventional representation of femininity by celebrating Irish women's commitment to the cause and highlighting how

\footnotetext{
16 Arguably, this is one of the reasons why The Wind that Shakes the Barley has been considered by some as "certainly superior” to Jordan's film, “[i]n terms of historical accuracy" (Coleman 2006: 2; Griffin 2006: 48). Loach's concern with authenticity is reflected in the cast of his film. In contrast to Neil Jordan, this film director refuses to include Hollywood stars in his films. He tried to choose as many amateur actors as possible (most of them, interestingly enough, Cork natives). Furthermore, Loach prefers to shoot sequentially, and the actors do not know the script or what happens to their characters until a day in advance or so. The result of this, as Kiberd (2006: 14) explains, is that "[a]t many moments, the actors seem to stumble over their sentences, as real people do in pressured situations of everyday life”. All this infuses Loach's film with what McGurk (2006: 20) has called "a gritty realism” which contrasts markedly with Jordan's sensationalist reconstruction of historical events.
}

the sacrifices they made were in no way inferior to those of the male characters. In the process, the women he represents challenge the formulaic image of Ireland as a passive and helpless maiden.

Central to the film are the three generations of women who live in the thatched farmhouse where the Irish rebels shelter on a number of occasions: old Peggy, her daughter Bernadette and her granddaughter Sinéad (with whom Damien begins a romance). Through these three female characters, we get a perfect sense not only of the multidimensional lives of women at the time but also of the pivotal role they played in the local guerrilla war led against the British. As McCoole (2003: 59-60) contends,

The work of Cumann na Mban in the aftermath of the Rising had a major effect in shaping the revolutionary spirit of the years 1917-1921 ..., it was the women who spread the doctrine of Republicanism throughout the country during the period when the men were interned.

The importance of Irish women in supporting and sustaining this patriotic movement is captured magnificently in The Wind that Shakes the Barley. As Ferriter (2006: 21) notes, Loach's "women are not there for decorative purposes, but are an important part of the action and the narrative". In his dramatic reconstruction, Volunteers and Cumann na mBan work together against the British authorities. They deliver food and letters to the rebels, hide weapons (an action which, as Laverty [2006: 12] explains, was "punishable by death"), produce propaganda and provide safe houses for the rebels; all vital activities in the success of the guerrilla campaign. In doing so, they risk their lives and the welfare of their families and homes. Loach stresses in his film the physical courage of these women, whose involvement with the IRA leaves them vulnerable to raids, attacks and reprisals from the British forces. He also portrays women who hold positions of power, presiding over Republican Courts and filling secretarial roles. Bearing all this in mind, it is not surprising that critics such as Gibbons (2006: 4) claim that "the film breaks new ground in highlighting the active role of women in the struggle”. 
In this sense, and in contrast to Jordan's film, Loach portrays more accurately the efforts and sacrifices not only of men but also of ordinary women in the fight for national freedom. In spite of this, it is interesting to note how this filmmaker maintains gender conventions in his representation of the Irish landscape. Some critics claim that Loach's film depicts the countryside in rather romanticized and idealistic terms. James (2006: 26) contends that "[a] cornerstone of Loach's effort here is to depict Ireland as a naturally gentle rural place populated by handsome freedom fighters battling the hateful, sadistic British soldier". Others such as Lawrenson (2006: 46) argue that this film offers "idyllic pastoral interludes": "[f]rom the woodland meeting place of Damien and Sinéad, their path edged by a green blaze of ferns, to the windwhispered hills of the volunteers' training ground". This beauty of the Irish landscape not only "confer[s] a stilled dignity to the nationalist struggle”, as Lawrenson (2006: 46) explains, but also, to my mind, maintains a whole tradition that conceptualizes land and land ownership as a politicized (and by extension feminine) category.

This becomes particularly obvious if we consider the most recurrent setting in which the action occurs: the countryside farmhouse which is inhabited, from the very beginning, by the three generations of women. Ireland (its landscape and its history) seems to be allegorized in terms of this simple cottage, which is, in turn, gendered feminine by its female inhabitants. The regular appearance of this setting as the site where numerous British atrocities are committed reinforces the colonial allegory of Ireland as a female victim of imperialist rule. In the film, the farmhouse is raided and attacked on three separate occasions: it becomes the place where a local boy is murdered at the beginning of the film, it later becomes the site of Sinéad's physical assault by the British forces, and finally the locus of a humiliating raid from the Free State Army. According to Lawrenson (2006: 47), "the linking of repeated instances of statesanctioned terror to the same location may ... suggest the tragic circularity of Irish history”. Indeed, Loach seems to suggest that history repeats itself: the brutality exerted by the Black and Tans is virtually replicated by the new Free State Force, which violates the very same place that provided refuge to some of the same activists in the opening scenes. Nevertheless, this cyclic view of history also suggests the reinforcement of traditional conceptions of femininity and the land, and the maintenance of the age-old equation between woman and nation.

In one of the most violent and humiliating scenes in the film, Loach clearly utilizes the allegory of Ireland as a grieving maiden against whom terrible acts of male atrocities are committed. After an ambush against the British in the countryside, some of the Volunteers, Damien included, go to Peggy's farm to take refuge. Suddenly, they hear distant sounds. Hiding in the bushes, they helplessly witness how the Black and Tans forcefully drag Peggy, Bernadette and Sinéad out of their cottage and later set the house on fire (Laverty 2006: 102). Their aggression is particularly directed towards Sinéad. While a man holds her from behind, another officer cuts off her hair with some sheep shears, a form of punishment actually practised, as McCoole (2003: 86) explains. The scene is loaded with sexual connotations, not only in terms of the position of Sinéad's body (her legs are widely open as she sits on an old milking stool), but also in the attitude displayed by the British officers, who intersperse cheers and laughter with denigrating insults such as "Fenian whore”. Sineád's desperate screams while she is having her hair cut indirectly evoke the laments of the violated and abused figure of Mother Ireland. In her analysis of melodramas such as When Wexford Rose (1910) and For the Land She Loved (1915), both about the 1798 Rebellion led by Wolfe Tone, Butler Cullingford (2001: 79) explains how in these plays P.J. Bourke maintains "the gendered analogy in which the English male pursues an Irish woman, and recasts the pursuit as rape or attempted rape". In this scene, Loach also retains the colonial allegory of England as a male rapist and Ireland as the female victim. By violating Sinéad's body, the Black and Tans assert their position as colonizers/ conquerors of Ireland. ${ }^{17}$

\footnotetext{
17 This sexist attitude is also displayed at the beginning of the film, when the Black and Tans address offensive remarks to Bernadette and Peggy ("Shut up, you bitch!”, "You fucking sow!"). Towards the middle of Laverty’s screenplay, Sinéad
} 
In this sense, one of Loach's main concerns is to focus on how women's ordinary lives are affected by the public conflict, in order to highlight how their private domestic sphere is invaded and assaulted by the violent male world. Whereas in Michael Collins, Kitty is presented as a site of male protection (remember Collins's words, "I promised Harry to look after you" [Jordan 1996: 145]), in The Wind that Shakes the Barley, women, their bodies and existences are represented as common targets of British reprisal.

Although Loach clearly dramatizes the sexual dimensions of the colonial allegory, he nonetheless goes a step forward in terms of his portrayal of women by presenting valiant and determined female characters, who play their part in the struggle against British rule in Ireland. One of these women is Peggy. When commenting on how this character started to take shape in his screenplay for the film, screenwriter Paul Laverty (2006: 12) explains:

I imagined someone like Peggy as a child, experiencing eviction during the Famine, and then again in her thirties during the agricultural depression of the 1870s, perhaps with children. The Famine had such a catastrophic effect, and was in many ways the product of Ireland being a colony - even as the Irish starved the British continued to export food. Peggy has lived through so many injustice and pain she is a rebel to her marrow. She is absolutely opposed to British rule and under no circumstances will she allow herself to be evicted for a third time.

Peggy's character brings a human face to the tragedy of past events in Ireland (i.e. the Famine and the Land War in the late $19^{\text {th }}$ century). She emerges as a compelling communal figure, representative of the hunger and hardship endured by the Irish community. She also represents the permanence of tradition and the importance of Irish roots. When at the beginning of the film, Damien goes to Peggy's farmhouse to make his farewells before departing to London, she forcefully grabs him close and tells him with unmistakable dignity: "But remember where you come from .... And we want you back ...” (Laverty 2006: 46).

(..17) confronts a squad of British soldiers who stop her and check her bag while bantering between them (Laverty 2006: 57).
Later in the film, Peggy gives shelter to Gogan, a young soldier from Donegal who helps Damien and others to escape from prison. As in the previous line, she addresses this boy using the first person pronoun in the plural, thus enhancing this sense of community, belonging and shared identity: "You are a brave lad ... we won't forget ... We're going to look after you son .... [laying her hand on his shoulder] like one of our own" (Laverty 2006: 76-77). Peggy symbolizes tradition and ancestral lineage. She is a venerable woman, commanding respect by virtue of her age and the dignity of her 'race'. Significantly enough, she adopts a more prominent role in Laverty's screenplay than in Loach's adaptation, where her verbal interventions are reduced. In the film, Peggy is almost simplified into a national symbol, a symbol that is nonetheless subversive.

In the political poetry which emerged from the seventieth century onwards from the mouths of the Gaelic bards, the female persona of Ireland encounters the poet, engages in a dialogue with him and prophesies the return of Catholicism to Ireland. Whether allegorized as Spéir bhean, Roisín Dubh, Sean Bhean Bhocht or Cathleen ni Houlihan, this national icon always needs the action of a man (the hero Cú Chulainn for instance) to defeat the colonizer and restore her happiness. In contrast to this, Loach's new national icons are not helpless to resist the atrocities committed by the English. Unlike her daughter Bernadette, Peggy is never intimidated by the raiders. This is observed in the initial scene, where she openly challenges the squad of Black and Tans by muttering insults in Irish and ignoring the British corporal's order to remain outside of her house. In this sense, Peggy represents the invincible desire of the Irish to be free, risking whatever it takes to protect the rebels sheltered in her house. As McCoole (2003: 75) explains: "Those women who kept safe houses for the most wanted men had to be of a certain disposition. It was essential that they did not gossip and that they kept their nerve in difficult situations". Peggy is indeed one of these women "of a certain disposition", knowing how to keep her "nerve in difficult situations". In contrast to helpless Mother Ireland, she is an energetic and charismatic woman, who, despite her old age, does not depend on the valorous actions of her 'sons' to protect her household. 
Her strength and determination is reinforced in the aftermath of the second raid, when the Black and Tans set her house on fire. Damien asks her where he should take them until they restore the place from the ashes. Peggy's reaction is surprisingly stubborn:

She doesn't miss a beat as she continues to browse, and examines a blackened pot in an off-hand kind of way.

PEGGY: I was four when my father died of famine fever ... we were evicted

after that ... I had five children dangling from my skirt the second time ... [turning to him] I swore I'd never move again ... I'm not going anywhere ... unless in a box

SINÉAD: But Granma ... where are you going to stay?

PEGGY: I'll clean up the chicken coop. (Laverty 2006: 103).

Peggy refuses to leave the place in which she has lived for a long time. The terrible experiences of displacement and suppression she has been subject to increase her determination to stick to her own place, even if this place is torn down, destroyed or burned ${ }^{18}$. Although Sinéad has inherited her grandmother's strength, she cannot react in the same way. Peggy's apparent indifference to Sinéad's wretched state and her desire to live in the very same place where Micheail has been murdered provoke her granddaughter's nervous breakdown. Whereas sinéad is tempted to abandon her national aspirations for the sake of a life in peace (she pleads Damien to take her away from there, for "I don't want to end up like her! I want a life!” [Laverty 2006: 103]), Peggy is the only woman who exhibits absolute conviction throughout the film. The fact that she appears almost always in the farm yard of her house is not accidental. In this threshold location, the boundaries between the private home and the political battlefield become blurred. Peggy is, in this sense, a figure who stands in-between the

18 Peggy's determination is inherited by her granddaughter Sinéad, who, after a raid by the Free State forces, starts to refill the contents of a sack, taking the scattered seeds from the ground (Laverty 2006: 135). Both scenes reinforce the association of women and the land while highlighting at the same time these characters' strength in sticking to their place. political and the domestic. By extension, her cottage becomes not only a site of conflict but also one of indomitable resistance.

Peggy's determined and powerful presence in Loach's film is reflected more by what she does not say than by what she says. In fact, it is her silence that makes her such a commanding figure. When Micheail is killed, both Bernadette and Sinéad openly express their sorrow. In contrast, Peggy does not show her emotions in such an overt fashion and there is a strange detachment in her eyes. Later in the film, an Irish Free State squad carries out a humiliating search in Peggy's farmhouse, looking for weapons. While some soldiers look into sacks containing seed, others search inside an "old wooden chest" owned by Peggy, scattering her "cloths" and "underwear" on the ground, together with some other personal belongings (Laverty 2006: 135). A horrified Bernadette shouts at the boys "How could you! After all the times we gave you food and shelter!". Meanwhile, Peggy stands "rock-like, on the same spot the entire search", "without saying a word" (Laverty 2006: 135). Her silence contrasts noticeably with the grieving cries of Cathleen ni Houlihan, and infuses her character with an air of immense solemnity and authority ${ }^{19}$.

Thus we see that Peggy allegorizes, on the one hand, tradition, heritage and roots; and, on the other, an indomitable determination to fight back, to change the past for a better future.

\footnotetext{
1 The hardness and strength of countrywomen is consistently emphasized throughout Loach's film, as when Damien narrates to Sinéad how he had to shoot Chris (who he had known all his life) and later went to see his mother and inform her about the death of her son. When confronting the murderer of her young lad, this mother shows no emotion, something that Damien at first, interprets as misunderstanding: "I went down and I told his mother ... She... she just looked at me. And then she went in and she put on her shoes. And she came out and she said 'Take me to my child'” (Laverty 2006: 96). Like Peggy, this mother appears as a strong woman, toughened by life and by the hard circumstances she has been through. Rather than expressing her grief and crying out loudly, this mother reacts with silence and controlled hatred: "And we walked for six hours and she didn't say one word ... And I showed her the grave ... And then she turned to me and she said 'I never want to see your face again"” (96).
} 
Notice how she is dressed in the same way throughout the whole film. Unlike the other widows Loach portrays, Peggy always wears a black dress with a white handkerchief around her head. While the black colour represents her own mourning for the wounds inflicted upon her ancestral lineage, the white represents the strength of someone who, even though marked by the death of her ancestors, is determined to resist, to look into the future, to start anew. These contradictory pulls are clearly reflected in her character: she both allegorizes the past atrocities done to her people and an indestructible will to be alive, to resist and endure despite hardships.

Sinéad's character does not correspond either to the allegorical image of grieving Mother Ireland. As an activist of a local branch of Cummann na mBan, she plays a major part in the campaign against the British. At various stages, Sinéad delivers intelligence and hides weapons, fighting the war alongside the men just as other anonymous female characters in the film $\mathrm{do}^{20}$. In scene $6 \mathrm{~B}$, Sinéad cycles on a solid bicycle to the place where the volunteers are hiding in a little cottage in order to deliver a message from Finbar. A few scenes later, she informs Damien of the identity of the informer who betrayed both him and his comrades to the British (78). Sinéad's role is no less dangerous than attacking barracks or laying ambushes, as evidenced by the violent reprisal that is inflicted on her by British officers. Risking her own life, she enters a pub and gives the volunteers some stolen guns hidden under her coat. With these pistols, they burst into the backroom bar and shoot four British 'Auxiliaries' dead ${ }^{21}$. Sinéad is also an active

\footnotetext{
${ }^{20}$ Although not visible on screen, we hear about other women working in the background, who are equally active in the guerrilla fight: Máire, “a typist” who copies British letters, and Clare, a landlord's servant who steals a British uniform from the laundry (Laverty 2006: 78, 97).
}

21 Although finally deleted in the film, Laverty includes a scene afterwards in which two women, standing in front of the pub, get the guns back, bundle them inside a "pram" and after covering them with "bedding", "march swiftly across the street" (Laverty 2006: 64). This scene shows how female activists used the resources of women's position as mothers and caretakers in order to challenge colonial rule. This is certainly accurate, for, as McCoole (2003: 73) courier during the Civil War, as reflected in scene 36, where she delivers a message from Dublin informing the anti-Treatyites about the defeat of their republican comrades at the Four Courts (119). In this sense, and in contrast to apolitical Kitty, Sinéad is willing to give her life for the sake of her ideals. In this respect, a comparative analysis of women's location in the two films is interesting. In The Wind that Shakes the Barley, women tend to move freely between private and public settings. At different stages, we see, for instance, Sinéad cycling through the woods, or standing at the entrance of a pub with the Volunteers. In Michael Collins, Kitty seems to be much more constricted in her movements. She is usually located in a private setting (often a bedroom hotel). If she is in a more public setting, she generally appears in male company (holding arms with Boland and/or Collins).

Furthermore, Sinéad's romance with Damien differs a great deal from Mick and Kitty's platonic relationship. The lovers in Loach's film do not conform to the standards of "virtuous hero" and "virginal heroine" that Hopper (1997: 16) identifies in Michael Collins. Whereas in this film it is not absolutely clear whether Collins and Kitty consummate their love, the hero and the heroine in The Wind that Shakes the Barley give way to their passion, and, after celebrating the truce between the British army and the IRA, they start making love as the light fades to dark (Laverty 2006: 106-107). Furthermore, and unlike vulnerable Kitty, Sinéad is the one who gives her man the necessary solace and support with which to confront the harsh environment of which he is a part. In one of their initial encounters, Sinéad, seeing the fear and vulnerability in Damien's eyes, gives him a St Christopher medal which belonged to her brother Micheail: "[It] will give you courage", she says (Laverty 2006: 59). Later in the film, she continues offering her unconditional support. When Damien tells her "I can't take much more of this", Sinéad holds him tight and whispers "You did well" (77). Sinéad is not a helpless and frail maiden, in the same way as Damien does not conform to the heroic figure

\footnotetext{
(...21) explains, many women during the War of Independence "collected and distributed material from their babies’ prams”.
} 
of male-nationalist discourse, fighting with inexhaustible bravery for the sake of his own country. Quite the contrary, Damien is presented as a vulnerable creature, unable to protect Sinéad from the British reprisals. When she is attacked by the Black and Tans, Damien, the male hero, is left completely powerless and is forced to witness the assault against his beloved. Damien is a contradictory hero, full of ambivalent feelings, and initially reluctant to engage in the fight against the British (much to Sinéad's contempt, who tells him, "So we all buy a one-way ticket to London?” [Laverty 2006: 53]). Sinéad, by contrast, has the strength and determination of her grandmother.

Despite the many ways in which The Wind that Shakes the Barley differs markedly from Michael Collins in terms of their portrayal of gender roles, both films are united in their location of the political sphere in the interstices of the heroes' personal relationships with their beloveds. In a scene that is reminiscent of Jordan's Bloody Sunday sequence, Laverty intermingles the brutality of war with a romantic scene between Damien and Sinéad. In contrast to Mick's dispassionate and colder attitude towards Kitty, Damien openly expresses his desire and affection to Sinéad:

DAMIEN: That night I was at my lowest ... couldn't sleep ... I saw a shooting star ... made me think of you...

SINÉAD: You know what that means? ... Another soul released from purgatory ... wonder who it was...

DAMIEN: After that I slept ... [pause, eye to eye] ... dreamt I put my hand upon your heart and made love with you ...

Silence for a long moment.

SINÉAD: I want time with you Damien O’Donovan.

He turns towards her.

SINÉAD (CONT'D): I do. A long time. (Laverty 2006: 96-97)

As in Michael Collins, the openly political is fused with the private and the intimately personal. In Loach's adaptation of Laverty's scene in the screenplay, the romantic discourse of "shooting stars" and idealistic dreams disappears entirely, enhancing the cruelty of
Damien's actions rather than the romance between both characters. In any case, the fusion of the personal and the political is there in both cases.

As in Michael Collins, the male heroic love for the mother country parallels the love story between a man and a woman. Neither Sinéad nor Kitty get to see their dream of marriage come true, just as Collins and Damien die without fulfilling their utopian visions of Ireland. In this sense, love for your partner and love for your mother country are incompatible (as the lyrics of the traditional folk song "The Wind that Shakes the Barley" make clear). On this point, Gibbons (1996: 265) compares Jordan's film with W.B. Yeats play Cathleen $\mathrm{Ni}$ Houlihan, since in both cases "Michael forgoes marriage to a real woman and sacrifices his life on the altar of Mother Ireland" (in Rockett and Rockett 2003: 173). At the end of the film, this critic continues, Kitty Kiernan never becomes a "'real' woman - married with family". The dream of Mother Ireland can only be achieved by the heroic selfsacrifice of the male character, and not by his marriage with Kitty. In this sense, the achievement of national independence is truncated by this inability to rejoin the private domestic sphere of women and the public political world of men: "Suspended between the (private) maternal and the (public) paternal, with no possibility of return but unable to progress further, Collins's fate tragically allegorizes the incomplete narratives of the nation itself” (Gibbons 1996: 268). In a way, this is also the case of the hero and heroine in The Wind that Shakes the Barley. Like Kitty, Sinéad's relationship with a man seems to be truncated by her lover's aspirations for national liberty. In any case, and in contrast to the apolitical heroine of Michael Collins, Sinéad plays a more active role in what Gibbons (1996: 268) identifies as "the (public) paternal" sphere. The divisions between women's private realm and men's public sphere are more blurred in this film, thus making possible the connection between the political and the personal. Therefore, it is not surprising that Damien, unlike Collins, gets to say goodbye to his lover, by writing a letter before his execution:

In time, look after Teddy. I'm afraid, inside, he's already dead. As the clock ticks on, I 
imagine your heartbeat under my hand. I hold the medal you hung around my neck and I tremble inside, it will give you courage, too ... Goodbye, Sinéad. I love you now, and always will. (Laverty 2006: 143-144)

At the film's conclusion, we are given the impression that the future is left open for Sinéad. Relying on her fortitude and strength, Damien pleads with her lover to take care of his brother. Whereas "life without" Michael "seems impossible" for Kitty (Jordan 1996: 91), the audience knows that Sinéad, although similarly devastated when hearing the news of Damien's death, will abide and endure as a result of her fortitude and unbreakable spirit.

Loach's celebration of women's vital role in the nationalist struggle and the subsequent Civil War also extends to other female characters in the film. At one stage, we witness a new Republican Court in session, one of the many set up in 1919 "to provide a legal system for Ireland that would replace the existing system operated by the British administration” (McCoole 2003: 74). This court is presided by "Lord Chief Justice” Lily, a politically-minded local magistrate (Laverty 2006: 89). Lily rules against Sweeney, a local merchant, for charging excessive interest rates on a loan to Mrs Rafferty, an impoverished housewife. The court is crowded not only with Volunteers from the IRA, but also with members of Cumann na mBan. Among them, we find Sinéad and another woman, who are sitting at a separate table assisting Lily in taking notes and giving her documents. As a socialist thinker, Lily decides to rule in favour of Mrs Rafferty on the grounds that, if they defend the rights of the accommodated bourgeoisie, they will merely be imitating the oppressive system of justice that was put in place by the British and against which they are meant to be fighting:

LILY: Frankly, I have some sympathy for Mrs Rafferty's position .... This is an extortionate rate of interest and an abuse of your position in the community ... this isn't an English court ... but a Republican Court ... we hereby order you to repay Mrs Rafferty the sum of 12 shillings and sixpence which still gives you a tidy profit ... you have seven days in which to pay ... thank you ... (Laverty 2006: 91).

While Lily's intervention in Laverty's screenplay is almost identical to the one in the film, it is significant to note how Loach emphasizes even more the authority of this character by changing the pronoun 'we' for the more assertive use of the first person in the singular: "I hereby order you to repay Mrs Raffety ten shillings and sixpence”. Challenging the authority of the female magistrate, Teddy intervenes and decides to take Sweeney to a pub in order to sort things out in his own way. In contrast to Lily, Teddy believes that Sweeney should not be punished, as IRA volunteers depend on the money of businessmen like Sweeney to buy arms and support them financially. An enraged Lily leaves the court with Sinéad in order to summon Teddy back. The way this scene appears in the original screenplay differs to some extent to Loach's filmic adaptation. Both versions shed significant light on Irish women's participation, and on how men react towards their authority. Therefore, it is worth contrasting them. In Laverty's original screenplay, a furious Lily leaves the courthouse in search of Teddy, as she screams with incisive authority:

LILY: Teddy O’Donovan ... come here!

TEDDY: I'll be with you in a second, Lily....

LILY: No. Now!

Teddy stares up at her and reluctantly follows her into the hallway. The volunteers, greatly entertained, are now on their feet.

NED: Come on, boys ... we can't miss this!

They all rush up the steps after Teddy and Leo.

In the hallway: the volunteers crowd around Lily, Sinéad, Teddy, and Leo

LILY:... who in the hell do you think you are to interfere with a court decision?

LEO: Calm down, Lily ...

SINÉAD: Answer the question ... by whose authority?!

TEDDY: For God's sake ... do you want every merchant in Ireland up against us?

LEO: You can't make decisions like that, girls....

LILY: Smug arrogant bastard!

Tim and Ned relish their growing anger

TIM: Sock it to 'em, 'Your Honour'

Chuckles from Tim and Ned, which spreads to others (Laverty 2006: 92). 
In this scene, the film anticipates the future division that develops among the Volunteers after the signing of the Treaty in 1921, which will lead to a vicious Civil War: while people like Teddy and Leo argue in favour of maintaining the status quo of the middleclasses, Lily, Sinéad, and others (i.e. Dan and Damien) believe in the creation of a socialist community which will deal with the problems of the lower classes ${ }^{22}$. In any case, this political discussion reveals something else: the chauvinistic stance of some of the Volunteers. While the Proclamation of the Republic gave equal rights to women (as evinced in Lily's active role as a Court magistrate), the conservative stance of some politicians will limit the political participation of future generations of women. All this is implied in the scene where Leo scorns Lily's decision and her little knowledge of politics ("You can't make decisions like that, girls...”). Later, Rory, another Volunteer, takes the floor, ridiculing her even more forcefully:

Who gives a damn, you silly woman? We have a war on! And here we are quibbling like a bunch of old fish wives! We have a job to do... with one objective ... drive the English out of Ireland! (Laverty 2006: 94).

Lily's power to enforce the law is therefore undermined by virtue of her gender: as a woman, she is believed to lack political effectiveness, and rather than potentially apt to govern she is in need of guidance. This patriarchal belief is also reflected in the

\footnotetext{
22 In his portrayal of the Civil War as a struggle between left-wingers (Fianna Fáil) and right-wingers (Fine Gael), Loach has been accused by critics of privileging in his film his socialist agenda over historical accuracy. As Ferriter (2006: 21) argues, Loach "flies the socialist flag more regularly than it was flown in Ireland in 1921", and others such as Coleman (2006: 2) maintain that Loach exaggerates "the influence of left-wing politics in the treaty debate”. O’Hanlon (2006: 26) also attacks Loach on the grounds that he reinterprets history from his "pernicious" socialist ideology and "Marxist dogma”. Perhaps the sharpest criticism has come from Sweeney's (2006: 31) column in The Sunday Independent, where he claims that Loach has made "a Marxist fantasy movie” by falsely portraying the Civil war "as a struggle between Marxists and rightwingers", when in reality "the IRA had no interest in overthrowing capitalism”.
}

attitude of some of the Volunteers witnessing the event: Tim and Ned are chuckling and giggling, clearly amused by the spectacle of a woman confronting the decisions of leaders such as Teddy. While Teddy's status is not questioned at all, Lily's challenging authority triggers Tim's amusement, who consequently ironically utters: "Sock it to 'em, 'Your Honour'”. Significantly enough, at the end of the scene, Lily and Sinéad remain silent; it is now the men who take the floor to engage in a violent dispute about the Ireland they want to create. Although the character of Lily is initially assertive and authoritative, at the end of the scene she seems to slip back, like Sinéad, into the conventional passivity and submission traditionally ascribed to women.

Lily's assertive stance and the subsequent chauvinistic attitude of some of the Volunteers also appear in Loach's adaptation of the original screenplay. After finally forcing Teddy back into the courthouse, a heated discussion follows between Teddy, on the one side, and Lily and Sinéad on the other. When, at one point, Teddy is being accused by Sinéad of interfering with a court's decision, he angrily replies: "Are you going to throw me into jail? Who'll fight the war then? You?”. In the film, it is Teddy who uses his masculine authority to undermine Lily's decision, and, in particular, to undervalue women's active participation under the assumption that they lack the necessary power to wage war against the British ${ }^{23}$. In this sense, both versions of the scene -Laverty's original screenplay and Loach's filmic adaptation- tackle issues concerning gender conventions and the controversies that arouse in the establishment of (female) power. In both cases, Teddy and Rory are the ones who challenge more aggressively Lily's authority, while Damien and Dan are portrayed as enforcing her

\footnotetext{
23 This chauvinist attitude is also displayed by a local priest who, during his sermon, preaches against the anti-Treatyites and accuses them of “spout[ing] communist poison”. When Lily speaks out, the priest shouts: "Young lady! This isn't the market place! Sit down, shut up, or get out of my church" (Laverty 2006: 133). His comment reveals the patriarchal assumption that women, if outside the domestic sphere, should limit their agency to the market place, a locale more suited to their gender.
} 
decision in the court. Raising his voice in favour of Lily, Dan claims:

Enough my fucking arse. [to Tim and Ned] ... The IRA backed the landlords ... and crushed people like you and me! [To Teddy and Leo] And here they go again ... backing a local bigwig and selling out a mother, just like yours, with no penny in her pocket ... fucking hilarious which side we end up on ... what do you think boys? (Laverty 2006: 95)

Significantly enough, and even though Dan fiercely demands respect for Lily's decision in court, he retains the eloquence of a patriotic dialect which fuses the national and the feminine. Dan accuses his fellow comrades of betraying their own nationhood and 'deserting' Mrs Rafferty, a poor mother and presumably a widow (as she is dressed in black). Dan's effective discourse partly relies on the allegorical equation of Ireland as an abandoned mother, betrayed by her own sons, who "sell [her] out" for the sake of preserving the privileged position of the upper middle class. Dan's speech suggests, in this sense, the permanence of the conventional association of woman and nation.

This is also observed in the heated postTreaty debates that Loach depicts ${ }^{24}$. After remembering the death of all the dead martyrs, the "absent faces" of the IRA ("Kevin, Johnny, Colm... murdered in the barracks .... Benny, shot in the back while cutting turf ... Aidan, tortured and then hung"), Finbar emphatically highlights the death of Micheail over all the others, for his killing was the most terrible: "Micheail! Jesus, I could go on all day, but we can't forget Micheail! He was beaten to a pulp in front of his mother!” (Laverty 2006: 110). Of all the deaths, his is the most terrible, for it was tragically witnessed by his helpless

\footnotetext{
${ }^{24}$ In contrast to Jordan, Loach stresses more deeply the importance of these political discussions in shaping Ireland's future by including a (perhaps excessively) long scene. Precisely because of this, his film has been criticized by critics such as Elley (2006: 41) for being more talk than guerrilla action. Against these charges, Loach argues: "Certain things can only be expressed in language. Images are too ambiguous. The Civil War was a struggle of ideas. It was a struggle for political position. It was a struggle of class interests. And you find that in language” (in Carty 2006a: 8).
}

mother. His remembrance deeply moves all the members assembled, which implies that the figure of the mother is something untouchable and sacred for them, its importance and significance surpassing all other things. This also seems to be the case for Damien, who questions his own involvement in the war when remembering his encounter with Chris's mother (Laverty 2006: 96). After raiding Peggy's farmhouse, Leo (now working for the Irish Free State), experiences a similar feeling when confronting this venerable woman: he feels "embarrassed" and "suffers under her gaze” (Laverty 2006: 135). Thus we see that, for all these rebels, the mother is an essential foundational element at the basis of their community. While Loach deconstructs conventional images of femininity and reverses gendered relations of power, he still relies on the importance that motherhood (and by extension metaphorical Mother Ireland) exerts on the rebels' minds. In the process, he also celebrates the fortitude and strength of women in the past by incorporating their political activities or resistance to oppression in their daily lives.

\section{Conclusion}

Whereas Michael Collins is the epic story of one male hero, The Wind that Shakes the Barley is the story of many heroes and heroines. An analysis of the role played by women in these two films reveals that, in Jordan's dramatic reconstruction, women do not get the appreciation that they deserve, since Michael Collins only offers passing references to women's participation in the nationalist struggle and the subsequent Civil War. By contrast, Loach's historical adaptation paints a truer picture of Irish women as active forces in the long struggle to achieve national selfdetermination. In his film, we can see not only glimpses of the ordinary actions women performed, as caretakers and mothers, but also the resistance to oppression they engaged in. As Carty (2006b: 11) explains, characters such as Peggy and Sinéad "personif[y] the often overlooked role women played in bringing about an independent Ireland".

The analysis of both films' representations of women also highlights the strong effect that the image of Woman-Ireland still has on contemporary filmmakers. Jordan keeps intact 
conventionalized images of women in the Irish tradition. Characters such as Kitty Kiernan personify the allegory of Ireland as both virginal and maternal: she is both a defeated mother and an asexual maiden. By contrast, Loach's female characters not only epitomize but also transcend the metaphorical relation of woman and nation. The defenceless entity of
Irish nationalism is here transformed into powerful and self-sufficient women such as Peggy, Sinéad and Lily, characters of great determination in their political convictions. Although still maintaining its iconic status, Loach's grieving Mother Ireland is also a charismatic woman of immense substance and authority.

\section{Works Cited}

Browne, Harry. 1996. "Contrived relationships mar Collins movie". The Irish Times, 18 December. http://www.ireland.com/newspaper/features/1996/1218/archive.96121800095.html Access: November 2006.

Butler Cullingford, Elizabeth. 2001. Ireland's Others: Gender and Ethnicity in Irish Literature and Popular Culture. Cork: Cork University Press \& Field Day.

Carey, Anna. 2006. "A review of The Wind that Shakes the Barley", The Sunday Tribune, December 24. 24-26.

Carty, Ciaran. 2006a. "Ken threw the rule book out". The Sunday Tribune, 18 June. 8. 2006b. "The Winds of change for Irish history". The Sunday Tribune, 25 June. 11.

Clayton-Lea, Tony. 2006. "Film Choice: A review of The Wind that Shakes the Barley". The Irish Times (Magazine), 7 March. 71.

Coleman, Shane. 2006. "Civil War of words". The Sunday Tribune (Tribune Review), 4 June. 1-2.

Coogan, Tim Pat. 1991. Michael Collins: A Biography. London: Arrowbooks.

Crowdus, Gary. 1996. "Neil Jordan's Michael Collins". America's Leading Magazine of the Art and Politics of the Cinema 22 (4): 14-19.

Dillon-Malone, Aubrey. 1996. Michael Collins (Movies Made in Ireland). Dublin: GLI Limited.

Dwyer, Michael. 1996. "The big film about the Big Fella". The Irish Times, 31 August. http://www.ireland.com/newspaper/weekend/1996/0831/archive.96083100177.html Access: December 2006. . 2005. "A Vision of Independence". The Irish Times (Weekend Review), 9 July. 7.

Elley, Derek. 2006. "Review of The Wind that Shakes the Barley". Film Review, 22-28 May. 41.

Ferriter, Diarmaid. 2006. "Loach's film gets it right". The Sunday Business Post, May 21. 21.

Gibbons, Luke. 1992. "On the Beach". Artforum International, October 3(2): 13. . 1996. "Engendering the State: Narrative, Allegory and Michael Collins", Eire/Ireland, Fall/Winter 3/4: 261-269.

. 1997. "Framing History: Neil Jordan's Michael Collins". History Ireland 5, Spring (1): 47-51.

2006. "Introduction", in The Wind that Shakes the Barley: A Screenplay by Paul Laverty. Cork: Galley Head Press. 3-6.

Ging, Debbie. 2000. "Women in Film". Film West, Winter 42: 72-73.

Gritten, David. 1995. "A Heroic Effort". Los Angeles Times, 3 December. 4-7.

Harris, Eoghan. 1996. "Michael Collins: A Tale of Bad History and Art". The Sunday Times, 10 November (Access through the Irish Film Institute Archives, Dublin) . 2006a. "The Wind that Shakes the sneaking regarders". The Sunday Independent, 4 June. 23.

2006b. "Loach brings a lost world to life but loses the plot". Sunday Independent, 11 June. 26.

Hopper, Keith. 1997. "'Cat-Calls from the Cheap Seats': The third meaning of Neil Jordan's Michael Collins". The Irish Review, Autumn/ Winter, 21: 1-28.

James, Nick. 2006. "Kind hearts and bayonets". Sight and Sound, June 16 (6): 26.

Jordan, Neil. 1996. Michael Collins: The Complete Screenplay. New York: Penguin.

Kiberd, Declan. 2006. "Loach out to rescue his England". The Irish Times, 4 July. 14.

Landesman, Cosmo. 2006. "Missing in action" (A review of The Wind that Shakes the Barley). The Sunday Times (Culture), 25 June. 12.

Laverty, Paul. 2006. The Wind that Shakes the Barley: A Screenplay. Cork: Galley Head Press.

Lawrenson, Edward. 2006. "The crying of the wind". Sight and Sound, July 16 (7): 46-47. 
Loach, Ken. 2006. "Director's Note", in The Wind that Shakes the Barley: A Screenplay by Paul Laverty. Cork: Galley Head Press. 7-9.

McCoole, Sinéad. 2003. No Ordinary Women: Irish Female Activists in the Revolutionary Years 1900-1923. Dublin: The O'Brien Press.

McConnell, Daniel. 2006. "Two-faced tabloids sneer at film success but not in Irish editions". The Sunday Independent, 4 June. 4.

McGurk, Tom. 2006. "Film aims to teach the world about our troubled history". The Sunday Business Post, 28 May. 20

McKiernan, Padraic. 2006. "Ideology eclipses art for ill wind that shakes blarney". The Sunday Independent, 25 June. 8.

McSwiney, Seamas. 1996. "Treaty makers and film makers: An interview with Neil Jordan". Film West, Autumn 26: 10-16.

Meaney, Gerardine. 1998. "Landscapes of Desire: Women and Ireland on Film". Women: a cultural review 9(3): 237-251.

Myers, Kevin. 1996. "Kitty get your gun". The Irish Times, 12 October (Access through the Irish Film Institute Archives)

Ó Broin, León (ed.). 1996 (1983). In Great Haste: The Letters of Michael Collins and Kitty Kiernan. Dublin: Gill \& Macmillan.

O'Farrell, Elizabeth. 1917. "Events of Easter Week: Miss Elizabeth O'Farrell's Story of the Surrender". The Catholic Bulletin and Book Review, April 7(4): 265-270, 329-334.

O'Hanlon, Eilis. 2006. "It's the Marxism that shakes 'the Barley"'. Sunday Tribune, 2 July. 26.

Pramaggiore, Maria. 2006. "'Papa Don't Preach': Pregnancy and Performance in Contemporary Irish Cinema". The Irish in the US: Irishness, Performativity, and Popular Culture. Ed. Diane Negra. Durham \& London: Duke University Press. 110-129.

Roberts, Andrew. 2000. "Why are Brits the bad guys". The Evening Herald, 14 June. 25.

Rockett, Emer and Kevin Rockett. 2003. Neil Jordan: Exploring Boundaries. Dublin: The Liffey Press.

Ruane, Medb. 1996. "Life after Mick" (Interview with Kitty Kiernan's sons Felix and Michael), The Irish Times, 5 November.

http://www.ireland.com/newspaper/newsfeatures/1996/1105/archive.96110500088.html Access: December 2006.

Ryan, Meda. 1996. Michael Collins and The Women in His Life. Cork \& Dublin: Mercier Press.

Sweeney, Eamonn. 2006. "Ken Loach". The Sunday Independent, 6 August. 21. 